\title{
Influence of ambient storage condition on the nutritional quality of selected freeze dried instant Nigerian soups
}

\author{
Akeem Olayemi Raji ${ }^{*}$, Rahman Akinoso \\ ${ }^{1}$ Department of Food Science and Technology, College of Agriculture and Veterinary Medicine, Kwara State University, Malete, Ilorin, Nigeria \\ ${ }^{2}$ Department of Food Technology, Faculty of Technology, University of Ibadan, Nigeria \\ *Corresponding author: akeem.raji@kwasu.edu.ng
}

\begin{abstract}
Traditional soups are culturally acceptable soups that are rich in nutrients, but conventional preservation methods such as reheating after use and frozen storage diminish their nutrient qualities. Freeze drying is a dehydration method which has a great ability to retain food nutrients, but there is scanty of scientific data on its application to Nigerian soups preservation. Soups (Ila, Ewedu, Ogbono and Kuka) were prepared using standard recipes, freeze-dried, packaged in polyvinylchloride and stored at ambient condition for 8 weeks. Moisture, protein, fat, crude fibre, ash, carbohydrate, iron, calcium, sodium, potassium, phosphorus and vitamins were determined at 14 days interval using standard methods. Data were analysed using ANOVA at $p=0.05$. Moisture, protein, fat, crude fibre, ash and carbohydrate contents of the soups ranged from 6.33-7.57\%, 25.93$43.86 \%, 7.19-43.86 \%, 13.52-17.16 \%, 8.45-10.80 \%$ and $0.65-27.97 \%$ respectively. Iron, calcium, sodium, potassium and phosphorus varied from 9.26-13.47 mg/100g, 73.57-245.23 mg/100g, 150.78-281.72 mg/100g, 209.22-352.07 mg/100g and 286.18-363.52 mg/100g respectively. The predominant vitamins (mg/100g) were A (66.69-137.49), B (22.73-88.74) and E (64.20-207.23). Freeze-drying reduced soups moisture contents by 90.0-90.8\%, thus increased the concentrations of other constituents. The nutrients quality of the freeze dried soups was well maintained for a storage period of two months, but cannot be further guaranteed due to slight decrease in their fat contents which indicates an increase in lipid oxidation.
\end{abstract}

Keywords: Soups, Freeze drying, Preservation, Nutritional quality, Ambient storage

\section{Introduction}

Vegetables are good sources of vitamins (A, B, C, E), minerals and dietary fibre, they also play significant roles in human nutrition (Elemo et al., 2011). Vegetables and fruits contribute about $91 \%$ of vitamin $\mathrm{C}$ and $48 \%$ of vitamin A (Oboh, 2005a). Green leafy vegetables have been widely accepted as a dietary constituent in some parts of Nigeria, generally forming a dietary portion of substance in the preparation of soups and stews (Hart et al., 2005). Leafy vegetables are good sources of protein, mineral, vitamins, fiber and other nutrients which are usually in short supply in the rural dwellers daily diets (Mepba et al., 2007). They add taste, colour, flavour, variety, and appeal aesthetically to what might be otherwise referred to as monotonous diet (Raji et al., 2015). They are cultivated abundantly during the rainy season but they become scarce during the dry season. However, limiting basic preservation facilities for freezing, canning and dehydration make them to be rarely processed in Nigeria. Therefore, smaller quantities are sundried, giving rise to poor quality products with high moisture contents and microbial loads thus affecting storage stability (Mepba et al., 2007). Amongst these vegetables are "Ewedu" (Corchorus olitorus), "Ila" (Hibiscus esculentus), "Ogbono"(Irvingia gabonensis) and" Kuka"(Adansonia digitata).

Traditional dishes are one of the oldest and deeply ingrained aspects of African culture (Oguche, 2012). They are extremely health protective and rich in nutrient. Some traditional foods are good sources of proteins, omega-3 fatty acids and antioxidants (Kpikpi et al., 2009; Amadi et al., 2011; Benjamin et al., 2012b). Interestingly, different cultures have different traditional foods that are indigenous to them (Benjamin et al., 2012a; Benjamin et al., 2012b; Amadi et al., 2011; Benjamin et al., 2011). Traditional foods can be broadly classified in to two groups; the first group are the traditional dietary staples which consumed in the area where they are grown, for example, cassava, potatoes, plantains, cocoyam, yam and maize. The second group comprises of component of accompanying relishes and sauces, which include oilseeds, fruits and vegetables that are consumed along with the traditional dietary staples (Okeke et al., 2009). Indigenous or traditional soups are soups that are associated with a particular ethnic and cultural society (Raji et al., 2019). Investigations revealed that Nigerian soups are naturally rich in micronutrients, and their regular consumption might eventually prevent or reduce occurrences of some micronutrient deficiencies (Raji et al., 2015; Kayode et al., 2010). In spite of the richness of the Nigerian traditional soups in nutrients, their preservation by frozen storage and reheating after use declined their nutrient qualities (Raji et al., 2015).

The recent demand for good quality products in the food market necessitates dehydration of foods in such a way that the nutritional and organoleptic properties of the initial fresh products are maintained at a very high level (Mayor and Sereno, 2004). Fruits and vegetables have been dehydrated by different methods, but each method's implication on the final product qualities include degradation of the texture, colour and physiologically active compounds (Krokida et al., 2001). Freeze drying is among the best dehydration methods that retain the biological value of raw materials, their structure, flavour, aroma and colour, thereby making their final products to be easily reconstituted by simple addition of water (Jayathilakan et al., 2012). Freeze drying produces final product quality that is better than other dehydration methods such as air or drum drying (Hsuch et al. 2003). Utmost attention has been given to freeze drying by many researchers, Li et al. (2004) and Yun et al. (2006) revealed that dried sea cucumber with good quality attribute upon rehydration could be produced by freeze drying (FD). Paakkonen and Mattila (1991) reported that improved sensory quality of dried fruits could be achieved 
through low processing temperature such as freeze drying. Hammami and Rene (1997) reported that strawberry freeze dried at $20^{\circ} \mathrm{C}$ possessed better quality than when oven dried at $60^{\circ} \mathrm{C}$. This research work was under taken due to scanty of scientific data on the application of freeze drying to Nigerian soups preservation.

\section{Materials and methods}

\section{Nigerian Soups Preparation}

The standard recipes described by FIIRO (2006) were used for the preparation of Ewedu (Corchorus olitorus), ila (Hibiscus esculentus), ogbono (Irvingia gabonensis), and kuka (Adansonia digitata) soups. Their recipes were shown in Table 1 and the procedures for their preparation were described below:

Table 1. Recipes Used for Preparation of Soups

\begin{tabular}{|c|c|c|c|}
\hline Ogbono & Ewedu & Ila & Kuka \\
\hline Bitter Leaf(20g) & Leaves $(120 \mathrm{~g})$ & Okro(fruit(640g)) & Meat $(1000 \mathrm{~g})$ \\
\hline Ogbono (ground $(240 \mathrm{~g})$ ) & Egusi(ground $(40 \mathrm{~g}))$ & Pepper(14g) & Onion $(75 \mathrm{~g})$ \\
\hline Palm oil (80ml) & Water $(500 \mathrm{ml})$ & $U g w u(200 g)$ & Dry fish (50g) \\
\hline Water (2000ml) & Crayfish $(40 \mathrm{~g})$ & Meat(1000g) & Stockfish $(500 \mathrm{~g})$ \\
\hline Maggi (8g) & $\operatorname{Potash}(1 \mathrm{~g})$ & Crayfish(40g) & Kuka (Powder $(150 \mathrm{~g}))$ \\
\hline Onion (3400g) & $\operatorname{Iru}(5 \mathrm{~g})$ & Onion(300g) & Maggi (10g) \\
\hline Iru (locust beans (10g)) & Salt(5g) & Salt(14g) & Salt(8g) \\
\hline Fish(Smoked (310g)) & & Palm oil(40ml) & Curry(3g) \\
\hline $\operatorname{Meat}(1000 \mathrm{~g})$ & & Water(2000ml) & Thyme(1.4g) \\
\hline Crayfish(ground (40g)) & & Maggie cube $(8 g)$ & Crayfish $(30 \mathrm{~g})$ \\
\hline Periwinkle(deshelled (94g)) & & $\operatorname{Iru}($ locust beans $(10 \mathrm{~g}))$ & Water(2000ml) \\
\hline Salt(10g) & & & Palm Oil(100ml) \\
\hline Pepper(ground (14g)) & & & \\
\hline
\end{tabular}

Adapted from FIIRO (2006)

\section{Ewedu Soup Preparation}

Fresh 'ewedu' leaves were washed thoroughly with water to remove adherent dirt. The clean leaves were blended with a known quantity of water in a blender. It was then poured into a clean pot and a small quantity of potash was added to the blend. The blend was further boiled for $5 \mathrm{~min}$ and melon powder was sprinkled into the boiling mixture. The mixture was stirred gently and left to simmer on low heat for $5 \mathrm{~min}$. Locust bean, salt and ground crayfish were introduced into the mixture before heat was removed.

\section{Ogbono Soup Preparation}

Onions, meat and pieces of fish were washed thoroughly with clean water and the clean ingredients were placed in a clean pot having a known quantity of water. The items were boiled until they were thoroughly cooked. The cooked meat and fish were removed from the pot and minced to aid drying. The ground 'ogbono', minced fish, oil, minced meat, ground pepper, ground crayfish and periwinkles were introduced into the boiling mixture. The boiling mixture was gently stirred and allowed to simmer for 5 min before chopped vegetable and seasoning introduced. It was further allowed to boil for $5 \mathrm{~min}$ before heat was removed.

\section{Ila Soup Preparation}

Onions, fish and meat were washed thoroughly and placed in a clean pot having known amount of water. The items were boiled until they become cooked. The boiled fish and meat were removed from the pot and minced to aid drying. Oil, ground crayfish, minced meat, minced fish, and ground pepper were added to the boiling mixture. The mixture was stirred gently and allowed to boil for $10 \mathrm{~min}$. Thereafter chopped okro fruits and seasoning were introduced and left until the okro softened and the required consistency was achieved.

\section{Miyan kuka Soup Preparation}

Onions, fish and meat were washed thoroughly with clean water and the items were placed in a clean pot having considerable amount of 
water. The mixtures were cooked for $25 \mathrm{~min}$. A mincing machine was used to mince the boiled meat, stock fish and dried fish in order to aid drying. The items that were minced were placed in a clean pot. Also, considerable amount of water, curry, and ground pepper were introduced into the mixture and it was further cooked for $20 \mathrm{~min}$. Miyan Kuka leaves powder was also introduced into the boiling mixture and it was stirred gently and allowed to steam for 15 min before heat was removed. All the soups were cooled and then packaged in stainless steel trays before freeze drying.

\section{Soups Freeze Drying}

Each freshly prepared soup $(350 \mathrm{~g})$ was spread in the drying trays and kept in freeze drying chamber of CRC FD-10N-50 model freeze dryer for 12-14 h. The temperature of the shelf was maintained at $25^{\circ} \mathrm{C}$, while the drying chamber pressure was kept at $80 \mathrm{~Pa}$ during drying. The cold trap temperature was kept at $-40{ }^{\circ} \mathrm{C}$. Each sample was dehydrated until final moisture content ranging from 6-7 \% w.b. was reached. Each dried soup was subsequently packaged in $0.1 \mathrm{~mm}$ poly vynil chloride bags and kept at room temperature for 8 weeks.

\section{Analyses}

Analyses such as proximate composition (moisture, protein, ash, fat, crude fibre and carbohydrate), mineral composition (iron, calcium, sodium, potassium and phosphorus) and vitamin contents (vitamin A, vitamin $B$ and vitamin $E$ ) of each soup sample were evaluated using the standard AOAC procedures (AOAC, 2005). Data obtained were analyzed by one-way ANOVA test using SPSS statistical programme.

\section{Results and discussion}

\section{Effect of Storage Period on the Proximate Composition of Freeze Dried Soups}

Proximate compositions of the freeze dried Nigerian soups were presented in Table 1. The storage period had significant influence on all the determined chemical properties at $95 \%$ confidence level, except for the fat content of ogbono and the ash content of kuka soup that were insignificant during ambient storage.

Table 2. Effect of Storage Period on the Proximate Composition of Freeze Dried Soups

\begin{tabular}{|c|c|c|c|c|c|c|}
\hline Sample & Moisture (\%) & $\begin{array}{l}\text { Protein } \\
(\%)\end{array}$ & $\begin{array}{l}\text { Fat } \\
(\%)\end{array}$ & $\begin{array}{l}\text { Ash } \\
(\%)\end{array}$ & $\begin{array}{l}\text { Crude } \\
\text { fibre(\%) }\end{array}$ & $\begin{array}{l}\text { Carbohydrate } \\
(\%)\end{array}$ \\
\hline \multicolumn{7}{|l|}{ Ewedu } \\
\hline 0 week & $6.33 \pm 0.11^{\mathrm{d}}$ & $34.33 \pm 0.36^{\mathrm{a}}$ & $7.60 \pm 0.13^{\mathrm{a}}$ & $8.45 \pm 0.11^{\mathrm{d}}$ & $16.00 \pm 0.11^{\mathrm{a}}$ & $27.28 \pm 0.71^{\mathrm{c}}$ \\
\hline 2 weeks & $6.57 \pm 0.07^{c}$ & $34.03 \pm 0.25^{\mathrm{ab}}$ & $7.44 \pm 0.04^{b}$ & $8.54 \pm 0.08^{\mathrm{d}}$ & $14.93 \pm 0.08^{b}$ & $28.49 \pm 0.31^{\mathrm{a}}$ \\
\hline 4 weeks & $7.22 \pm 0.05^{\mathrm{b}}$ & $33.86 \pm 0.06^{\mathrm{bc}}$ & $7.33 \pm 0.04^{\mathrm{bc}}$ & $8.99 \pm 0.08^{c}$ & $14.81 \pm 0.08^{b}$ & $27.79 \pm 0.17^{\mathrm{bc}}$ \\
\hline 6 weeks & $7.34 \pm 0.04^{\mathrm{ab}}$ & $33.57 \pm 0.09^{\mathrm{cd}}$ & $7.28 \pm 0.04^{\mathrm{cd}}$ & $9.29 \pm 0.05^{\mathrm{b}}$ & $14.65 \pm 0.05^{\mathrm{b}}$ & $27.86 \pm 0.07^{\mathrm{bc}}$ \\
\hline 8 weeks & $7.44 \pm 0.06^{\mathrm{a}}$ & $33.34 \pm 0.13^{\mathrm{d}}$ & $7.19 \pm 0.05^{\mathrm{d}}$ & $9.46 \pm 0.04^{\mathrm{a}}$ & $14.59 \pm 0.04^{\mathrm{b}}$ & $27.97 \pm 0.05^{\mathrm{ab}}$ \\
\hline \multicolumn{7}{|l|}{ Ila } \\
\hline 0 week & $6.92 \pm 0.12^{\mathrm{c}}$ & $43.86 \pm 0.17^{\mathrm{a}}$ & $8.51 \pm 0.06^{\mathrm{a}}$ & $10.12 \pm 0.25^{\mathrm{c}}$ & $17.00 \pm 0.24^{\mathrm{a}}$ & $13.59 \pm 0.59^{b}$ \\
\hline 2 weeks & $7.27 \pm 0.58^{\mathrm{bc}}$ & $43.49 \pm 0.17^{b}$ & $8.34 \pm 0.11^{\mathrm{b}}$ & $10.15 \pm 0.17^{c}$ & $16.97 \pm 0.17^{\mathrm{a}}$ & $13.78 \pm 0.30^{\mathrm{b}}$ \\
\hline 4 weeks & $7.36 \pm 0.02^{\mathrm{bc}}$ & $43.14 \pm 0.03^{\mathrm{c}}$ & $8.01 \pm 0.07^{\mathrm{c}}$ & $10.31 \pm 0.07^{\mathrm{bc}}$ & $16.80 \pm 0.09^{\mathrm{ab}}$ & $14.39 \pm 0.23^{\mathrm{a}}$ \\
\hline 6 weeks & $7.70 \pm 0.04^{\mathrm{ab}}$ & $42.74 \pm 0.11^{\mathrm{d}}$ & $7.82 \pm 0.03^{\mathrm{d}}$ & $10.54 \pm 0.02^{\mathrm{b}}$ & $16.58 \pm 0.08^{\mathrm{bc}}$ & $14.61 \pm 0.20^{\mathrm{a}}$ \\
\hline 8 weeks & $8.17 \pm 0.07^{\mathrm{a}}$ & $42.55 \pm 0.03^{\mathrm{d}}$ & $7.55 \pm 0.05^{\mathrm{e}}$ & $10.80 \pm 0.06^{\mathrm{a}}$ & $16.43 \pm 0.02^{\mathrm{c}}$ & $14.50 \pm 0.06^{\mathrm{a}}$ \\
\hline \multicolumn{7}{|l|}{ Ogbono } \\
\hline 0 week & $6.53 \pm 0.18^{b}$ & $26.86 \pm 0.16^{\mathrm{a}}$ & $43.60 \pm 1.17^{\mathrm{a}}$ & $9.83 \pm 0.14^{c}$ & $14.02 \pm 0.10^{\mathrm{a}}$ & $0.84 \pm 0.66^{\mathrm{a}}$ \\
\hline 2 weeks & $6.60 \pm 0.17^{b}$ & $26.67 \pm 0.11^{\mathrm{b}}$ & $44.19 \pm 0.05^{\mathrm{a}}$ & $9.92 \pm 0.12^{\mathrm{c}}$ & $13.93 \pm 0.06^{\mathrm{ab}}$ & $1.30 \pm 0.35^{\mathrm{a}}$ \\
\hline 4 weeks & $6.76 \pm 0.08^{b}$ & $26.37 \pm 0.08^{c}$ & $43.57 \pm 0.10^{\mathrm{a}}$ & $10.14 \pm 0.06^{\mathrm{b}}$ & $13.80 \pm 0.09^{\mathrm{b}}$ & $0.65 \pm 0.17^{\mathrm{a}}$ \\
\hline 6 weeks & $7.33 \pm 0.11^{\mathrm{a}}$ & $26.18 \pm 0.02^{\mathrm{d}}$ & $43.37 \pm 0.07^{\mathrm{a}}$ & $10.35 \pm 0.03^{\mathrm{a}}$ & $13.79 \pm 0.10^{\mathrm{b}}$ & $1.02 \pm 0.08^{\mathrm{a}}$ \\
\hline 8 weeks & $7.57 \pm 0.09^{\mathrm{a}}$ & $25.93 \pm 0.04^{\mathrm{e}}$ & $43.18 \pm 0.07^{\mathrm{a}}$ & $10.50 \pm 0.05^{\mathrm{a}}$ & $13.52 \pm 0.06^{\mathrm{c}}$ & $0.71 \pm 0.12^{\mathrm{a}}$ \\
\hline \multicolumn{7}{|l|}{ Kuka } \\
\hline 0 week & $6.35 \pm 0.07^{\mathrm{e}}$ & $39.79 \pm 0.91^{\mathrm{a}}$ & $9.57 \pm 0.20^{\mathrm{a}}$ & $9.70 \pm 0.31^{\mathrm{a}}$ & $17.16 \pm 0.04^{\mathrm{a}}$ & $17.43 \pm 0.82^{\mathrm{c}}$ \\
\hline 2 weeks & $6.56 \pm 0.11^{\mathrm{d}}$ & $39.27 \pm 0.21^{\mathrm{ab}}$ & $9.52 \pm 0.21^{\mathrm{a}}$ & $9.76 \pm 0.26^{\mathrm{a}}$ & $17.07 \pm 0.02^{\mathrm{b}}$ & $17.81 \pm 0.16^{\mathrm{bc}}$ \\
\hline 4 weeks & $6.77 \pm 0.10^{c}$ & $39.13 \pm 0.19^{\mathrm{ab}}$ & $9.36 \pm 0.13^{\mathrm{ab}}$ & $9.91 \pm 0 . .^{15 a}$ & $16.83 \pm 0.05^{\mathrm{c}}$ & $18.00 \pm 0.12^{\mathrm{a}-\mathrm{c}}$ \\
\hline 6 weeks & $6.94 \pm 0.05^{\mathrm{b}}$ & $38.88 \pm 0.03^{b}$ & $9.14 \pm 0.06^{\mathrm{bc}}$ & $9.98 \pm 0.10^{\mathrm{a}}$ & $16.53 \pm 0.06^{\mathrm{d}}$ & $18.53 \pm 0.02^{\mathrm{ab}}$ \\
\hline 8 weeks & $7.28 \pm 0.06^{\mathrm{a}}$ & $38.61 \pm 0.06^{\mathrm{b}}$ & $9.02 \pm 0.10^{c}$ & $10.07 \pm 0.03^{\mathrm{a}}$ & $16.33 \pm 0.06^{\mathrm{e}}$ & $18.68 \pm 0.13^{\mathrm{a}}$ \\
\hline
\end{tabular}

Mean values having different superscripts within a column are significantly different $(p<0.05)$ 


\section{Moisture Content}

The moisture contents of the freeze dried soups ranged from $6.33 \pm 0.11-$ $7.44 \pm 0.06 \%$ (ewedu), 6.92 $\pm 0.12-8.17 \pm 0.07 \%$ (ila), 6.53 $\pm 0.18-7.57 \pm$ $0.09 \%$ (ogbono) and 6.35 $\pm 0.07-7.28 \pm 0.06 \%(k u k a)$. Significant changes in chemical composition of the soups during storage might be attributed to water absorption capacity of the biomaterials which causes re-distribution of chemicals within a food (Akinoso and Lasisi, 2013). The moisture content of food determines their suitability to microbial attack and hence spoilage (Olusanya, 2008). Dehydration of foods is one of the most common processes used to improve food stability, since it decreases considerably with the water activity of the material, reduces microbiological activity and minimises physical and chemical changes during its storage (Mayor and Sereno, 2004). The observed low moisture contents $(6.33 \pm 0.11-8.17 \pm 0.07 \%)$ in all the soup samples during two months storage could mean that the soups might be shelf stable for more than two months. However, there was slight increase in the moisture content of all the soup samples packaged in $0.1 \mathrm{~mm}$ polyvinyl chloride bags as the storage period increased. Slight increase in the moisture content of the samples during storage might be attributed to water adsorption of low-moisture-content food powders from storage environment (Huaning and Benheng, 2013). Similar results were obtained by Koç et al. (2010) and Kumar and Misha (2004) and who reported that the moisture contents of mango soy fortified yoghurt powder under accelerated storage and spray-dried yoghurt powder under $25^{\circ} \mathrm{C}$ and $50 \% \mathrm{RH}$ increased slightly in 49 days and 90 days, respectively.

\section{Protein}

The protein contents of the freeze dried soups ranged from $33.34 \pm 0.13-$ $34.33 \pm 0.36 \%$ (ewedu), $42.55 \pm 0.03-43.86 \pm 0.17 \%$ (ila), $25.93 \pm 0.04-$ $26.86 \pm 0.16 \%$ (ogbono) and $38.61 \pm 0.06-39.79 \pm 0.91 \%$ (kuka). It was observed that as the storage period increased the protein content reduced. Protein quality is a measure of the usefulness of a food protein for the purpose of growth and maintenance of tissue. Reduction in crude protein content was due autolytic deterioration associated with the actions of endogenous enzymes and bacteria (Hultman and Rustard, 2004). High protein contents observed in the dried soup was as a result removal of moisture and the method of dehydration employed which prevented food quality losses during drying. This lays credence to the findings of Tao and Linchun (2008) who worked on influences of hot air drying and microwave drying on nutritional and odorous properties of grass carp (Ctenopharyngodon idellus) fillets.

\section{Fat}

The fat contents of the freeze dried soups ranged from $7.19 \pm 0.05$ $7.60 \pm 0.13 \%$ (ewedu), 7.55 $\pm 0.05-8.51 \pm 0.06 \%$ (ila),43.18 \pm 0.07 $43.60 \pm 1.17 \%$ (ogbono) and 9.02 $\pm 0.10-9.57 \pm 0.20 \%$ (kuka). It was observed that there was a significant increase in lipid contents of the soups, suggesting that freeze drying retained the fat contents of fresh soups subjected to dehydration. This was similar to the findings of Rahman et al. (2002) who worked on pores and physico-chemical characteristics of dried tuna produced by different methods of drying and Artharn et al, (2009) who researched on storage stability and its effectiveness for shelf-life extension of dried fish powder packaged in round scad protein-based film. It was also noticed that as the storage period increased the fat contents of the soups slightly reduced. The reduction in fat content indicates an increase in lipid oxidation. This could be due to the release of oxidative enzymes and prooxidants from various rupture cellular organelles (Boonsumrej et al., 2007). Variation in the fat contents might be as a result of different quantities of external red oil added to the soups as stated in the recipe book and the nature of the ingredient used as the case of ogbono soup, where the ogbono seed which is the major ingredient naturally had high fat content of $54-67 \%$ (Akusu and Kiin-Kabari, 2013). The lower level of fat in the freeze dried ewedu, ila and kuka samples gave a higher probability of a longer shelflife in terms of the onset of rancidity (Arisa et al., 2013).

\section{Ash}

The ash contents of freeze dried soups ranged from $8.45 \pm 0.11-9.46 \pm 0.04$ $\%$ (ewedu), $10.12 \pm 0.25-10.80 \pm 0.06 \%$ (ila), $9.83 \pm 0.14-10.50 \pm 0.05 \%$ (ogbono) and $9.70 \pm 0.31-10.07 \pm 0.03 \%(k u k a)$. It was observed that as the storage period increased the ash contents of all the soup samples increased. This trend was similar to the findings of Tao and Linchun (2008) who worked on influences of hot air drying and microwave drying on nutritional and odorous properties of grass carp (Ctenopharyngodon idellus) fillets. Ash content is an index of mineral contents in biota (Akubugwo et al., 2007). The observed high ash content in the soup samples suggested that they might contain high mineral values.

\section{Crude Fibre}

The crude fibre contents of the freeze dried soups ranged from $14.59 \pm 0.04$ $16.00 \pm 0.11 \%$ (ewedu), $16.43 \pm 0.02-17.00 \pm 0.24 \%$ (ila), $13.52 \pm 0.06$ $-14.02 \pm 0.10 \%$ (ogbono) and $16.33 \pm 0.06-17.16 \pm 0.04 \%$ (kuka). It was observed that as the storage period increased the crude fibre content reduced. Losses in crude fibre from all these soups were most probably dominated by enzyme-induced degradation (Martininez-Romero et al., 2004). Adequate intake of dietary fiber can lower the level of serum cholesterol and reduce the risk of developing hypertension, constipation, diabetes, colon, cancer and coronary heart disease (Ishida et al., 2000). Loss of moisture increases dry matter of which fibre is one and high fibre content of foods is good for quick bowl evacuation (Oguche, 2012). The observed high crude fibre content in the soup samples suggested that their consumption might reduce the risk of developing the aforementioned diseases.

\section{Carbohydrate}

The cabohydrate contents of the freeze dried soups ranged from $27.28 \pm 0.71-27.97 \pm 0.05 \%$ (ewedu), $13.59 \pm 0.59-14.50 \pm 0.06 \%$ (ila), $0.65 \pm 0.17-1.30 \pm 0.35 \%$ (ogbono) and $17.43 \pm 0.82-18.68 \pm 0.13 \%$ $(k u k a)$. However, there was a significant increase in the percentage carbohydrate contents of the dried soups, suggesting that freeze drying retained the carbohydrate contents of fresh soups subjected to dehydration. The recommended dietary allowance (RDA) values of carbohydrate for adults, pregnant and lactating mothers are $130 \mathrm{~g}, 175$ $\mathrm{g}$, and $210 \mathrm{~g}$ respectively (Durumajesty et al., 2012). The carbohydrate contents of the soups were very low, but this is not a concern since they are consumed along with starch based dietary staples (Kayode et al., 2010).

\section{Effect of Storage Period on the Mineral Compositions of Freeze Dried Soups}

The mineral compositions of the freeze dried Nigerian soups were presented in Table 3. The storage period had significant influence on all the mineral compositions of the selected freeze dried soups at $95 \%$ confidence level. 
Table 3. Effect of Storage Period on the Mineral Compositions of Freeze Dried Soups

\begin{tabular}{|c|c|c|c|c|c|}
\hline Samples & $\begin{array}{l}\text { Iron } \\
(\mathrm{mg} / \mathbf{1 0 0 g})\end{array}$ & $\begin{array}{l}\text { Calcium } \\
(\mathrm{mg} / \mathbf{1 0 0 g})\end{array}$ & $\begin{array}{l}\text { Sodium } \\
\text { (mg/100g) }\end{array}$ & $\begin{array}{l}\text { Potassium } \\
(\mathrm{mg} / 100 \mathrm{~g})\end{array}$ & $\begin{array}{l}\text { Phophorus } \\
\text { (mg/100g) }\end{array}$ \\
\hline \multicolumn{6}{|l|}{ Ewedu } \\
\hline 0 week & $13.42 \pm 0.52^{\mathrm{a}}$ & $245.23 \pm 2.65^{\mathrm{a}}$ & $236.29 \pm 1.05^{\mathrm{a}}$ & $276.78 \pm 0.05^{\mathrm{a}}$ & $362.43 \pm 0.08^{\mathrm{a}}$ \\
\hline 2 weeks & $13.35 \pm 0.49^{\mathrm{a}}$ & $245.10 \pm 2.60^{\mathrm{a}}$ & $236.14 \pm 1.01^{\mathrm{a}}$ & $276.71 \pm 0.59^{\mathrm{a}}$ & $362.37 \pm 0.10^{\mathrm{a}}$ \\
\hline 4 weeks & $13.29 \pm 0.50^{\mathrm{a}}$ & $244.97 \pm 2.57^{\mathrm{a}}$ & $235.97 \pm 0.90^{\mathrm{a}}$ & $276.42 \pm 0.03^{b}$ & $362.17 \pm 0.02^{\mathrm{b}}$ \\
\hline 6 weeks & $13.24 \pm 0.49^{\mathrm{a}}$ & $244.53 \pm 2.33^{\mathrm{a}}$ & $235.94 \pm 0.89^{\mathrm{a}}$ & $275.94 \pm 0.04^{\mathrm{c}}$ & $362.11 \pm 0.07^{\mathrm{b}}$ \\
\hline 8 weeks & $13.15 \pm 0.42^{\mathrm{a}}$ & $244.35 \pm 2.21^{\mathrm{a}}$ & $235.93 \pm 0.89^{\mathrm{a}}$ & $275.78 \pm 0.04^{\mathrm{d}}$ & $361.84 \pm 0.06^{\mathrm{c}}$ \\
\hline \multicolumn{6}{|l|}{ Ila } \\
\hline 0 week & $9.30 \pm 0.04^{\mathrm{a}}$ & $73.57 \pm 0.18^{\mathrm{a}}$ & $151.48 \pm 0.25^{\mathrm{a}}$ & $210.24 \pm 0.26^{\mathrm{a}}$ & $287.50 \pm 1.22^{\mathrm{a}}$ \\
\hline 2 weeks & $9.28 \pm 0.04^{\mathrm{a}}$ & $73.53 \pm 0.15^{\mathrm{ab}}$ & $151.25 \pm 0.11^{\mathrm{ab}}$ & $209.96 \pm 0.55^{\mathrm{ab}}$ & $286.63 \pm 0.44^{\mathrm{ab}}$ \\
\hline 4 weeks & $9.28 \pm 0.04^{\mathrm{a}}$ & $73.48 \pm 0.14^{\mathrm{ab}}$ & $151.08 \pm 0.11^{\mathrm{ab}}$ & $209.60 \pm 0.39^{b c}$ & $286.35 \pm 0.28^{\mathrm{ab}}$ \\
\hline 6 weeks & $9.26 \pm 0.04^{\mathrm{a}}$ & $73.41 \pm 0.13^{\mathrm{ab}}$ & $151.25 \pm 0.47^{\mathrm{ab}}$ & $209.41 \pm 0.17^{\mathrm{bc}}$ & $286.24 \pm 0.27^{\mathrm{b}}$ \\
\hline 8 weeks & $9.26 \pm 0.04^{\mathrm{a}}$ & $73.29 \pm 0.09^{b}$ & $150.78 \pm 0.04^{\mathrm{b}}$ & $209.22 \pm 0.14^{\mathrm{c}}$ & $286.18 \pm 0.25^{\mathrm{b}}$ \\
\hline \multicolumn{6}{|l|}{ Ogbono } \\
\hline 0 week & $13.47 \pm 0.05^{\mathrm{a}}$ & $153.80 \pm 0.06^{\mathrm{a}}$ & $210.59 \pm 0.08^{\mathrm{a}}$ & $290.50 \pm 0.50^{\mathrm{a}}$ & $387.19 \pm 0.07^{\mathrm{d}}$ \\
\hline 2 weeks & $13.22 \pm 0.07^{\mathrm{b}}$ & $153.44 \pm 0.06^{\mathrm{b}}$ & $209.78 \pm 0.10^{\mathrm{b}}$ & $289.93 \pm 0.06^{\mathrm{b}}$ & $387.08 \pm 0.07^{\mathrm{cd}}$ \\
\hline 4 weeks & $13.13 \pm 0.04^{\mathrm{bc}}$ & $153.40 \pm 0.05^{\mathrm{bc}}$ & $209.66 \pm 0.02^{\mathrm{bc}}$ & $289.81 \pm 0.10^{\mathrm{b}}$ & $386.97 \pm 0.07^{\mathrm{bc}}$ \\
\hline 6 weeks & $13.12 \pm 0.01^{\mathrm{bc}}$ & $153.34 \pm 0.06^{\mathrm{c}}$ & $209.54 \pm 0.09^{c}$ & $289.75 \pm 0.07^{\mathrm{b}}$ & $386.84 \pm 0.10^{\mathrm{ab}}$ \\
\hline 8 weeks & $13.09 \pm 0.08^{\mathrm{c}}$ & $153.34 \pm 0.07^{\mathrm{d}}$ & $209.26 \pm 0.06^{\mathrm{d}}$ & $289.63 \pm 0.08^{\mathrm{b}}$ & $386.79 \pm 0.07^{\mathrm{a}}$ \\
\hline \multicolumn{6}{|l|}{ Kuka } \\
\hline 0 week & $11.28 \pm 0.02^{\mathrm{a}}$ & $240.83 \pm 0.08^{\mathrm{a}}$ & $281.72 \pm 0.03^{\mathrm{a}}$ & $352.07 \pm 0.06^{\mathrm{a}}$ & $363.52 \pm 0.50^{\mathrm{a}}$ \\
\hline 2 weeks & $11.23 \pm 0.02^{\mathrm{b}}$ & $240.66 \pm 0.05^{\mathrm{b}}$ & $280.85 \pm 0.05^{\mathrm{b}}$ & $351.88 \pm 0.02^{\mathrm{b}}$ & $362.77 \pm 0.01^{\mathrm{bc}}$ \\
\hline 4 weeks & $11.22 \pm 0.02^{\mathrm{b}}$ & $239.76 \pm 0.10^{c}$ & $280.61 \pm 0.06^{c}$ & $351.82 \pm 0.01^{\mathrm{bc}}$ & $362.88 \pm 0.56^{\mathrm{b}}$ \\
\hline 6 weeks & $11.21 \pm 0.02^{\mathrm{b}}$ & $239.59 \pm 0.13^{\mathrm{cd}}$ & $280.38 \pm 0.10^{\mathrm{d}}$ & $351.80 \pm 0.03^{\mathrm{c}}$ & $362.44 \pm 0.02^{\mathrm{bc}}$ \\
\hline 8 weeks & $11.19 \pm 0.03^{\mathrm{b}}$ & $239.47 \pm 0.10^{\mathrm{d}}$ & $280.34 \pm 0.04^{\mathrm{d}}$ & $351.74 \pm 0.03^{\mathrm{d}}$ & $362.21 \pm 0.03^{c}$ \\
\hline
\end{tabular}

Mean values having different superscripts within a column are significantly different $(p<0.05)$

\section{Iron}

The iron contents of the freeze dried soups ranged from $13.15 \pm 0.42$ $13.42 \pm 0.52 \mathrm{mg} / 100 \mathrm{~g}$ (ewedu), 9.26 $\pm 0.04-9.30 \pm 0.04 \mathrm{mg} / 100 \mathrm{~g}$ (ila), $13.09 \pm 0.08-13.47 \pm 0.05 \mathrm{mg} / 100 \mathrm{~g}$ (ogbono) and $11.19 \pm 0.03-11.28 \pm 0.02$ $\mathrm{mg} / 100 \mathrm{~g}(k u k a)$. Ewedu was observed to have the highest concentration of Iron, while Ila had the lowest concentration. It was observed that there was a slight reduction in the iron contents of the soups as the storage period increased. Soups selected had appreciable levels of iron content. Iron is an important component of the red blood cells, which enhances the oxygen-carrying capacity of the red blood cells (Sanni et al., 2010). The adult RDA for iron is $10 \mathrm{mg} /$ day for men and $15 \mathrm{mg} /$ day for women indicating that the selected soups will be able to meet the daily dietary iron requirements (Kayode et al., 2010; Wardlaw, 1999). High level of Iron in the soups might probably due to the ingredients and inclusion of meat which is a source of iron (Onabanjo and Oguntona, 2003). This corresponds to earlier reports that most Nigerian natural foods are rich in iron (Latunde-Dada, 1997). Openheimer (2000) reported that Iron deficiency was extremely common in the developing world, with less than $50 \%$ of the world's population having some degree of deficient iron status based on a wide variety of tests.

\section{Calcium}

The calcium contents of the freeze dried soups ranged from 244.35 \pm 2.21 $245.23 \pm 2.65 \mathrm{mg} / 100 \mathrm{~g} \quad$ (ewedu), $73.29 \pm 0.09-73.57 \pm 0.18 \mathrm{mg} / 100 \mathrm{~g}$ (ila), $153.34 \pm 0.07-153.80 \pm 0.06 \mathrm{mg} / 100 \mathrm{~g}$ (ogbono) and $239.47 \pm 0.10$ $240.83 \pm 0.08 \mathrm{mg} / 100 \mathrm{~g}(k u k a)$. It was observed that there was a slight reduction in the iron contents of the soups as the storage period increased. Calcium is one of the macro minerals needed in highest amounts by the body cells (Sanni et al., 2010). The selected soups had relatively high levels but not sufficient to meet the Adequate Intake (AI) of calcium for adults (1000-1200mg/day) and adolescence (1300 mg/ day). Deficiency of calcium might lead to osteoporosis in later life (Allen, 2001). This makes supplementation very important. Flesh and sea foods are often included in these soups and also consumed with tuber or cereal-based dishes such as cooked cassava, yam, plantain, rice or maize- based dishes thus improving the calcium level.

\section{Sodium}

The sodium contents of the freeze dried soups ranged from $235.93 \pm 0.89$ $236.29 \pm 1.05 \mathrm{mg} / 100 \mathrm{~g}$ (ewedu),150.78 $\pm 0.04-151.48 \pm 0.25 \mathrm{mg} / 100 \mathrm{~g}$ (ila), $209.26 \pm 0.06-210.59 \pm 0.08 \mathrm{mg} / 100 \mathrm{~g}$ (ogbono) and 280.34 $\pm 0.04-$ $281.72 \pm 0.03 \mathrm{mg} / 100 \mathrm{~g}(k u k a)$. The sodium contents of the soups slightly reduced as the storage period increased. The observed moderate content 
of sodium in the soup samples suggested that they might contribute to proper functioning of the body system (Sanni et al., 2010). Sodium intake of less than $2 \mathrm{~g} /$ day increases calcium loss in urine and high intakes can contribute to hypertension in some people (Wardlaw and Kessel, 2002). Sodium is the major positive ion in the extracellular fluid and a key factor in retaining body water. Under the FDA food-label ingredients, the Daily Value for sodium is $2400 \mathrm{mg}$ (Greely, 1997). Consumption of large amounts of these soups would be important to meet the recommended daily allowance (RDA) for sodium.

\section{Potassium}

The potassium contents of the freeze dried soups ranged from $275.78 \pm 0.04-276.78 \pm 0.05 \mathrm{mg} / 100 \mathrm{~g}$ (ewedu), 209.22 $\pm 0.14-210.24 \pm 0.26$ $\mathrm{mg} / 100 \mathrm{~g}$ (ila), 289.63 $\pm 0.08-290.50 \pm 0.50 \mathrm{mg} / 100 \mathrm{~g}$ (ogbono) and $351.74 \pm 0.03-352.07 \pm 0.06 \mathrm{mg} / 100 \mathrm{~g}(k u k a)$. Reduction in potassium content was minimal as the storage period increased. Potassium plays a similar role with sodium in the biological system, but it is located in the intracellular fluid. Unlike sodium it is associated with lower rather than higher blood pressure values (Wardlaw, 1999). Potassium level of the freeze dried soups was high, but it is far below the RDA (2000 mg/day). Deficiency in potassium leads to an irregular heartbeat, loss of appetite and muscle cramps (Kayode et al., 2010). Since these soups are often not consumed alone, but with other food types which could improve the potassium level, the RDA mentioned above might be met.

\section{Phosphorus}

The phophorus contents of the freeze dried soups ranged from $361.84 \pm 0.06-362.43 \pm 0.08 \mathrm{mg} / 100 \mathrm{~g}$ (ewedu), $286.18 \pm 0.25-287.50 \pm 1.22$ $\mathrm{mg} / 100 \mathrm{~g}$ (ila), 386.79 \pm 0.07-387.19 $\pm 0.07 \mathrm{mg} / 100 \mathrm{~g}$ (ogbono) and $362.21 \pm 0.03-363.52 \pm 0.50 \mathrm{mg} / 100 \mathrm{~g} \quad(k u k a)$. Ogbono was observed to have the highest concentration of Iron, while ila had the lowest concentration. It was observed that there was a slight reduction in the phosphorus contents of the soups as the storage period increased. Analysis of phosphorus in food products is also very important because it contributes to bone development. Its deficiency might accelerate bone loss in elderly people, most especially women (Wardlaw,1999; Kayode et al., 2010). High level of phosphorus observed depicts that the soups can meet the daily requirements of phosphorus (RDA for adults is $>700$ $\mathrm{mg} /$ day).

\section{Effect of Storage Period on the Vitamin Contents of Freeze Dried Soups}

The vitamin compositions of the freeze dried Nigerian soups were presented in Table 4 . The storage period had significant influence on all the vitamin compositions of the selected freeze dried soups at $95 \%$ confidence level.

Table 4. Effect of Storage Period on the Vitamin Compositions of Freeze Dried Soups

\begin{tabular}{|c|c|c|c|}
\hline Sample & $\begin{array}{l}\text { Vitamin A } \\
(\mathrm{mg} / \mathbf{1 0 0 g})\end{array}$ & $\begin{array}{l}\text { Vitamin B } \\
(\mathrm{mg} / \mathbf{1 0 0 g})\end{array}$ & $\begin{array}{l}\text { Vitamin E } \\
(\mathrm{mg} / \mathbf{1 0 0 g})\end{array}$ \\
\hline \multicolumn{4}{|l|}{ Ewedu } \\
\hline 0 week & $67.13 \pm 0.05^{\mathrm{a}}$ & $22.87 \pm 0.03^{\mathrm{a}}$ & $64.63 \pm 0.05^{\mathrm{a}}$ \\
\hline 2 weeks & $66.80 \pm 0.02^{\mathrm{b}}$ & $22.77 \pm 0.01^{\mathrm{c}}$ & $64.30 \pm 0.02^{\mathrm{c}}$ \\
\hline 4 weeks & $66.94 \pm 0.01^{\mathrm{c}}$ & $22.82 \pm 0.00^{\mathrm{b}}$ & $64.45 \pm 0.01^{\mathrm{b}}$ \\
\hline 6 weeks & $66.73 \pm 0.02^{\mathrm{d}}$ & $22.75 \pm 0.01^{\mathrm{cd}}$ & $64.24 \pm 0.02^{\mathrm{d}}$ \\
\hline 8 weeks & $66.69 \pm 0.05^{\mathrm{d}}$ & $22.73 \pm 0.02^{\mathrm{d}}$ & $64.20 \pm 0.05^{\mathrm{d}}$ \\
\hline \multicolumn{4}{|l|}{ Ila } \\
\hline 0 week & $137.49 \pm 0.32^{\mathrm{a}}$ & $32.34 \pm 0.08^{\mathrm{a}}$ & $207.23 \pm 0.50^{\mathrm{a}}$ \\
\hline 2 weeks & $136.85 \pm 0.17^{b}$ & $32.19 \pm 0.04^{\mathrm{b}}$ & $206.24 \pm 0.26^{b}$ \\
\hline 4 weeks & $137.45 \pm 0.08^{\mathrm{a}}$ & $32.33 \pm 0.02^{\mathrm{a}}$ & $207.14 \pm 0.12^{\mathrm{a}}$ \\
\hline 6 weeks & $136.63 \pm 0.19^{b}$ & $32.13 \pm 0.05^{\mathrm{b}}$ & $205.90 \pm 0.29^{b}$ \\
\hline 8 weeks & $136.02 \pm 0.16^{\mathrm{c}}$ & $31.99 \pm 0.04^{\mathrm{c}}$ & $204.99 \pm 0.24^{c}$ \\
\hline \multicolumn{4}{|l|}{ Ogbono } \\
\hline 0 week & $97.99 \pm 0.10^{\mathrm{a}}$ & $89.42 \pm 0.07^{\mathrm{a}}$ & $181.70 \pm 0.15^{\mathrm{a}}$ \\
\hline 2 weeks & $97.91 \pm 0.01^{\mathrm{ab}}$ & $89.32 \pm 0.01^{\mathrm{b}}$ & $181.50 \pm 0.02^{b}$ \\
\hline 4 weeks & $97.85 \pm 0.02^{\mathrm{b}}$ & $89.26 \pm 0.01^{\mathrm{b}}$ & $181.39 \pm 0.03^{b}$ \\
\hline 6 weeks & $97.68 \pm 0.02^{\mathrm{c}}$ & $89.11 \pm 0.02^{\mathrm{c}}$ & $181.08 \pm 0.04^{c}$ \\
\hline 8 weeks & $97.27 \pm 0.01^{\mathrm{d}}$ & $88.74 \pm 0.01^{\mathrm{d}}$ & $180.32 \pm 0.02^{\mathrm{d}}$ \\
\hline \multicolumn{4}{|l|}{ Kuka } \\
\hline 0 week & $98.00 \pm 0.03^{\mathrm{a}}$ & $54.76 \pm 0.03^{\mathrm{a}}$ & $91.18 \pm 0.06^{\mathrm{a}}$ \\
\hline 2 weeks & $97.80 \pm 0.02^{\mathrm{ab}}$ & $54.63 \pm 0.01^{\mathrm{b}}$ & $91.01 \pm 0.02^{\mathrm{ab}}$ \\
\hline 4 weeks & $97.60 \pm 0.01^{\mathrm{bc}}$ & $54.52 \pm 0.01^{\mathrm{bc}}$ & $90.83 \pm 0.01^{\mathrm{bc}}$ \\
\hline 6 weeks & $97.44 \pm 0.03^{\mathrm{c}}$ & $54.43 \pm 0.01^{\mathrm{c}}$ & $90.67 \pm 0.02^{\mathrm{c}}$ \\
\hline 8 weeks & $96.81 \pm 0.26^{d}$ & $54.08 \pm 0.15^{\mathrm{d}}$ & $90.08 \pm 0.24^{\mathrm{d}}$ \\
\hline
\end{tabular}

Mean values having different superscripts within a column are significantly different $(p<0.05)$ 


\section{Vitamin A}

The vitamin A contents of the freeze dried soups ranged from 66.69 $\pm 0.05-$ $67.13 \pm 0.05 \mathrm{mg} / 100 \mathrm{~g}$ (ewedu), 136.02 $\pm 0.16-137.49 \pm 0.32 \mathrm{mg} / 100 \mathrm{~g}$ (ila), 97.27 $\pm 0.01-97.99 \pm 0.10 \mathrm{mg} / 100 \mathrm{~g}$ (ogbono) and $96.81 \pm 0.26-98.00 \pm 0.03$ $\mathrm{mg} / 100 \mathrm{~g}$ (kuka). It was observed that there was a slight reduction in the vitamin A contents of the soups as the storage period increased. Evaluation of the stability of vitamin A is important in food materials as it acts as antioxidants (Jayathilakan et al., 2012). Effect of freeze drying and hot air drying on the stability of carotenoids in Taiwanese mango was studied by Chen et al., (2007) and they reported better retention of pigments in freeze dried samples during normal temperature of storage. Vasquez-Caicedo et al. (2007) also reported about 93\% retention of $\beta$-carotene during storage of carrot powder. The slight loss of vitamin A that is occurring during storage at room temperature for the period of two months might be due to autoxidation. The highly unsaturated chemical structure makes them very susceptible to thermal degradation and oxidation (Jayathilakan et al., 2012). Also, freeze dried products are generally more porous and this facilitates oxygen transfer and promotes oxidation of carotenoids which is a vitamin A precursor (Khallouf et al., 2000). Based on the data established above, it was evident that the freeze drying process and storage at ambient temperature exhibited good stability of vitamin A in all the freeze dried samples subjected to storage. The positive effect of temperature and storage in the degradation of vitamin A in freeze dried samples was also reported by Cinar (2005).

\section{Vitamin B}

The vitamin B contents of the freeze dried soups ranged from $22.73 \pm 0.02-$ $22.87 \pm 0.03 \mathrm{mg} / 100 \mathrm{~g}$ (ewedu), 31.99 $\pm 0.04-32.34 \pm 0.08 \mathrm{mg} / 100 \mathrm{~g}$ (ila), $88.74 \pm 0.01-89.42 \pm 0.07 \mathrm{mg} / 100 \mathrm{~g}$ (ogbono) and 54.08 $\pm 0.15-54.76 \pm 0.03$ $\mathrm{mg} / 100 \mathrm{~g}(k u k a)$. The vitamin B content of the soup slightly reduced as the storage period increased. Fruits, vegetables and their products in the dried form are good sources vitamins. However, during the process of dehydration and storage, vitamin B was found to be more susceptible to thermal and oxidative degradation (Mustapha, 2013). Thiamin serves as a co-enzyme of carbohydrate metabolism. Ogbono soup had the highest thiamin content when compared with other soup samples. This might be as a result of ingredients formulation used in the preparation of the soups. High thiamine contents observed in the dried soups was as a result removal of moisture and the method of dehydration employed which prevented loss of quality during drying (Khallouf et al., 2000).

\section{Vitamin E}

The vitamin $E$ contents of the freeze dried soups ranged from $64.20 \pm 0.05$ $64.63 \pm 0.05 \mathrm{mg} / 100 \mathrm{~g}$ (ewedu), $204.99 \pm 0.24-207.23 \pm 0.50 \mathrm{mg} / 100 \mathrm{~g}$ (ila), $180.32 \pm 0.02-181.70 \pm 0.15 \mathrm{mg} / 100 \mathrm{~g}$ (ogbono) and $90.08 \pm 0.24-$ $91.18 \pm 0.06 \mathrm{mg} / 100 \mathrm{~g}(k u k a)$.The freeze dried soups contained vitamin $\mathrm{E}$ in high concentrations and the variation in the loss of vitamin $\mathrm{E}$ of the soups under investigation demonstrated the differences in vulnerabilities of the selected soup to spoilage during storage at ambient temperature (DuruMajesty et al., 2012, Bramley et al., 2000). There was a slight reduction in vitamin $\mathrm{E}$ content of the dried soups as the storage period increased. The degradation rate of vitamin $\mathrm{E}$ depends on oxygen availability, temperature, water activity and storage time, as well as on the fat content and food composition (Bramley et al., 2000). The poly vinyl chloride packaging material used to package the dried soups had barrier to moisture but not to air (Fellow, 2000).

\section{Conclusions}

The vitamins, protein, fat, crude fibre, carbohydrate, ash contents and mineral contents of the freshly freeze dried soups increased as a result of removal of moisture and the method of dehydration employed which prevented food quality losses during drying. However, there was slight increase in the moisture content and decrease in vitamins, protein, fat, crude fibre, carbohydrate, ash contents and mineral contents of all the soup samples packaged in $0.1 \mathrm{~mm}$ polyvinyl chloride bags as the storage period increased. However, the nutrients quality of the freeze dried soups cannot be guaranteed after two months of storage because due to slight decrease in their fat contents which indicates an increase in lipid oxidation.

\section{References}

Akinoso R., Lasisi I.M. (2013) Effect of Cooking Time on Select Physical and Mechanical Properties of Dried Pigeon pea (Cajanus cajan). The West Indian Journal of Engineering, 35(2) 45-50.

Akubugwo I.E., Obasi N.A., Chinyere G.C., Ugbogu A.E. (2007) Nutritional and chemical value of Amaranthus hybridusL. Leaves from Afikpo, Nigeria. African Journal of Biotechnology, 6(24) 2833-2839.

Akusu O.M., Kiin-Kabari D.B. (2013) Effect of storage period on selected functional, chemical stability and sensory properties of bush mango (irvingia Gabonensis) seed flour. African Journal of Food Science and Technology, 4(6)136-140.

Allen L.H. (2001) Micronutrients. 2020 Focus 5 (Health and Nutrition Emerging and Reemerging Issues in Developing Countries), Brief 10 of 11 , February 2001

Amadi B.A., Ayalogu E.O., Onyeike E.N. (2011) Nutrient and antinutrient composition of "Onunu" and "Mgbam", traditional foods of Ikwerre ethnic nationality in South-South, Nigeria. Journal of Emerging Trends in Engineering and Applied Sciences, 2(3) 551-555.

AOAC (2005) Official Methods of Analysis of the Association of Official Analytical Chemistry, AOAC, Washington DC, USA.

Arisa N.U., Adelekan A.O., Alamu A. E., Ogunfowora E.J. (2013) The Effect of Pretreatment Of Plantain (Musa Parasidiaca) Flour On The Pasting And Sensory Characteristics Of Biscuit. International Journal of Food and Nutrition Science, 2(1) 10-24.

Artharn A., Prodpran T., Benjakul T. (2009) Round scad protein-based film: Storage stability and its effectiveness for shelf-life extension of dried fish powder. LWT - Food Science and Technology 42 1238-1244.

Benjamin A. A, Eugene N.O., Edward O.A. (2012b) Mineral content and sensory evaluation of "Onunu" and "Mgbam", traditional diets of the Ikwerre people of Nigeria. Archives of Applied Science Research, 4 (1) 330-335.

Benjamin A.A, Eugene N.O., Edward O.A. (2011) Fatty and amino acid composition of "Onunu" and "Mgbam", traditional diets of the Ikwerre people of Nigeria. Continental Journal Food Science and Technology, 5 (1) 37-45.

Benjamin A., Amadi E.O. Ayalogu E., Onyeike N. (2012a) Performance characteristics and organ weight of rats, fed "Onunu" and "Mgbam" traditional diets of the Ikwerre people of Niger Delta, Nigeria. Continental Journal Food Science and Technology, 6 (1) 12 - 19.

Boonsumrej S., Chaiwanichsiri S., Tantratian S. (2007) Effect of freezing and thawing on the quality changes of tiger shrimp (Penaeus monodon) frozen by air-blast and cryogenic freezing. Journal of Food Engineering, 80(1) 292-299.

Bramley P.M., Elmadfa I., Kafatos A., Kelly F.J., Manios Y., Roxbor-Ough, H.E. (2000) Review of Vitamin E. Journal of Science, Food and Agriculture, 80 913-938.

Chen J.P., Tai C.Y., Chen B.H. (2007) Effects of different drying treatments on the stability of carotenoids in Taiwanese mango (Mangifera indica L.). Food Chemistry, 100 1005-1010.

Cinar I. (2005) Carotenoid pigment loss of freeze-dried plant samples under different storage conditions. LWT-Food Science and Technology, 37 
363-367.

DuruMajesty K.C., Agomuo E.A, Amadi B.A. (2012) Nutrient composition of "Nduduagworagwo", a traditional food of Akokwa people in Ideato North L.G.A of Imo State, Nigeria. Continental Journal of Food Science and Technology, 6(3) 27-32.

Elemo G.N., Elemo B.O., Oladunmoye O.O., Erukainure O.L. (2011) Comprehensive investigation into the nutritional composition of dehulled and defatted African locust bean seed (Parkia biglobosa). African Journal of Plant Science, 5(5) 291-295.

Fellows P. (2000) Food Processing Technology Principles and Practice. Woodhead Publishing Ltd., Cambridge, UK.

FIIRO (2006) Soup Recipe Book. Federal Institute of Industrial Research, Oshodi, Nigeria.

Greely A. (1997) A pinch of controversy shakes up dietary salt. FDA consumer.

Hammami C., Rene F. (1997) Determination of freeze-drying process variables for strawberries. Journal of Food Engineering, $32133-154$.

Hart A.D., Azubuike C.U., Barimalaa I.S. and Achinewhu, S. C. (2005) Vegetable consumption pattern of households in selected areas of the old Rivers State in Nigeria. African Journal of Food, Agriculture, Nutrition and Development, 5(1)1-19.

Hsuch L., Chen W., Weng Y.M., Tseng C.H.Y. (2003) Chemical com-position and antioxidant activity of yam as affected by drying methods. Food Chemistry, 83 85-92.

Huaning Y., Benheng G. (2013) Storage stability of freeze-dried colostral whey powders with different additives. International Journal of Agriculture \& Biology, 6(2) 95-107.

Hultman L., Rustard T. (2004) Iced storage of Atlantic salmon (Salmo salar) effects on endogenous enzymes and their impact on muscle proteins and texture. Food Chemistry, 87 31-34.

Ishida H., Suzuno H., Sugiyama N., Innami S., Todoro T., Maekawa A. (2000) Nutritional evaluation of chemical components of leaves, stalks and stem of sweet potatoes (Ipomea betatas poir). Food Chemistry, 68 359-367.

Jayathilakan K., Sultana K., Pandey M.C., Radhakrishna K. (2012) Effect of freeze-drying and storage on $\beta$-carotene and ascorbic acid stability of mango milk shake. International Journal of Food Fermentation and Technology, 2(2) 137-143.

Kayode F.O., Ozumba A.U., Ojeniyi S., Adetunji D.O., Erukainure O.L. (2010) Micronutrient Content of Selected Indigenous Soups in Nigeria. Pakistan Journal of Nutrition, 9(10) $962-965$.

Khalloufi S., Giasson J., Ratti C. (2000) Water activity of freeze dried mushrooms and berries. Canadian Agricultural Engineering, 42 (1) 51-56.

Koç B., Yilmazer M. S., Balkír P., Ertekin F. K. (2010) Moisture sorption isotherms and storage stability of spray-dried yogurt powder. Drying Technology, 28(6) 816-822.

Kpikpi E. N., Dzogbefia V.P., Glover R.K. (2009) Enzymatic and some biochemical changes associated with the production of "Kantong”, a traditional fermented condiments in Northern Ghana. Journal of Food Chemistry, 33 (1) 61-73.

Krokida M.K., Maroulis Z. B., Saravacos, G.D. (2001) The effect of the method of drying on the colour of dehydrated products. International journal of food science \& technology, 36 (1) 53-59.

Kumar P., Mishra H.N. (2004) Storage stability of mango soy fortified yoghurt powder in two different packaging materials: HDPP and ALP. Journal of Food Engineering, 65 (4) 569-576.

Latunde-Dada G. (1997) Sources and forms of iron in Nigerian foods and effects of processing on availability. Food Nutrition. Bull., 18 84-89.

Li Z.P., Fu P., Yang W.Y., Xu Z. (2004) Study on the freeze-dry processing technology of Stichopus japonicus. Marine Fisheries, 26 (1) $52-55$.

Martinez-Romero D., Castillo S., Valero D. (2004) Quality Control in Frozen Vegetables, University Miguel Hernandez, Orihuela, Alicante, Spain.

Mayor L., Sereno A.M. (2004) Modelling shrinkage during convective drying of food materials: A Review Journal of Food Engineering, 61 373-386. Mepba H.D., Eboh L., Banigo D.E.B. (2007) Effects of processing treatments on the nutritive composition and consumer acceptance of some Nigerian edible leafy vegetables. African Journal of Agricultural Nutrition and Development, 7 (1) 1-18.

Mustapha R.A. (2013) Nutrients composition of some traditional soups consumed by postpartum mothers in Nigeria. Journal of Pharmacy and Biological Sciences, 5 40-44.

Oboh G. (2005a) Effect of some post-harvest treatments on the nutritional properties of Cnidoscolus acontifolus leaf. Pakistan Journal of Nutrition, 4 (4) $226-230$

Oguche G.H.E. (2012) The effect of sun and shade drying on chemical composition of Vitex doniana, Ipomoea aquatica and Cohcorus and their soups. International Journal of Nutrition and Metabolism, 4 (9)121-129.

Okeke E.C., Eneobong H.N., Uzuegbunam A.O., Ozioko A.O., Umeh S.I., Kuhnlein H. (2009) Nutrient Composition of Traditional Food and their Contribution to Energy and Nutrient Intakes of Children and Women in Rural Households in Igbo Culture Area. Pakistan Journal of Nutrition, 8 (4) $304-312$.

Olusanya J.O. (2008) Essential of food and Nutrition.1st edition Apex book limited. 36-76. Nigeria

Onabanjo O.O., Oguntona, C.R.B. (2003) Iron, zinc, copper and phytates content of standardized Nigerian dishes. Journal of Food Composition and Analysis, 16 669-676.

Openheimer S.J. (2000) Iron and its relation to immunity and infectious disease. Journal of Nutrition, 131 616-633.

Paakkonen K., Mattila M. (1991) Processing, packaging and storage effects on quality of freeze dried strawberries. Journal Food Science, 561388 1392.

Rahman M.S., Al-Amri O.S., Al-Bulushi I.M. (2002) Pores and physico-chemical characteristics of dried tuna produced by different methods of drying. Journal of Food Engineering, 53 301-313.

Raji A.O., Akinoso R., Sani M., Raji M.O. (2019) Sensory Properties and Stability of Selected freeze-dried Nigerian Soups Stored at Ambient condition. Applied Tropical Agriculture, 24 (1)191-199.

Raji A.O., Akinoso R., Raji M.O. (2015) Effect of freeze-thaw cycles on the nutritional quality of some selected Nigerian soup. Food Science and Nutrition, 4 (2) 163-180.

Sanni S.A., Oguntona C.R.B., Maziya-Dixon B. (2010) Nutritional composition and sensory properties of iron fortified fufu flour. Journal of Natural Sciences, Engineering and Technology, 9 (1) 40-57.

Tao W., Linchun M. (2008) Influences of Hot Air Drying and Microwave Drying on Nutritional and Odorous Properties of Grass Carp (Ctenopharyngodon idellus) Fillets. Food Chemistry,110 (3) 647-653.

Vasquez-Caicedo A.L., Schilling S., Carle R., Neidhart S. (2007) Effects of thermal processing and fruit matrix on B-carotene stability and enzyme inactivation during transformation of mangoes into puree and nectar. Food Chemistry, 102 1172-1186.

Wardlaw G.M., Kessel M.W. (2002) Minerals: Dietary needs, absorption, transport and excretion. In: Perspectives in Nutrition (5 ${ }^{\text {th }}$ ed), Mc Graw-Hil Companies; pp 418-464.

Wardlaw G.N. (1999) Perspective in nutrition. 4th Ed., McGraw-Hills, Boston, pp 472-500.

Yun X., Han X.H., Nong S.Z., Yang H. (2006) Technological condition of vacuum freeze-drying in Stichopus japonicus. Journal of Fishery Sciences of China, 13 (4). 